\title{
Histological Evaluation of Bone Regeneration Means Freeze Dried Bone Allograft (FDBA) in Post Exodontia Sockets
}

\author{
Evaluación Histológica de la Regeneración Ósea en Alvéolos \\ Post Exodoncia Mediante Uso de Freeze Dried Bone Allograft (FDBA)
}

\author{
"Ramón Fuentes; "Gonzalo Oporto Venegas; "Sergio Olate; "*Mariana Rojas Rauco; "Eduardo Borie \& ${ }^{* * *}$ Wilfried Engelke
}

FUENTES, R.; OPORTO, V. G.; OLATE, S.; ROJAS, R. M.; BORIE, E. \& ENGELKE, W. Histological evaluation of bone regeneration means freeze dried bone allograft (FDBA) in post exodontia sockets. Int. J. Morphol., 29(1):286-292, 2011.

SUMMARY: Within oral rehabilitation alveolar ridge preservation following extraction is important. This research study shows a histological, histochemical and histomorphometrical evaluation in two cases of post extraction ridge-socket preservation performed with FDBA. In two patients dental extraction procedures were performed and sockets were immediately filled with FDBA. Six months later a biopsy of grafted area was obtained and rehabilitated through dental implant. Grafted bone samples were treated for histological and histochemical analysis. Bone tissue area was measured. Laboratory analysis of three samples showed inactive bone surfaces, neither osteoblasts nor osteoclasts were found, only osteocyte and osteogenous cells were observed. These findings do not mean that tissue is metabolically inactive, rather bone genesis develop from a tissue matrix with the potential to generate undifferentiated osteocytes, and a micro environment with proteins such as bone morphogenetic proteins (BPM). Inactive biomaterial particles were not observed. Samples showed $0 \%$ and $30 \%$ bone tissue respectively. Considering histological differences between this and other research studies, it is necessary to develop further investigation to increase knowledge of processes involved in bone regeneration as well as bone quality, considering the variability that could be seen in each patient.

KEY WORDS: Bone regeneration; Biomaterials; FDBA; Socket.

\section{INTRODUCTION}

It is possible to achieve bone regeneration and alveolar ridge increase by using autografts and biomaterials (Oporto et al., 2008). Autogenous grafts (AG) have presented high rates of success (Chapasco et al., 2008; Smolka et al., 2006; Lizuka et al., 2004; Cordaro et al., 2002; Antoun et al., 2001), with survival of dental implants very close to findings of nongrafted sites (Tonetti \& Hammerle 2008). Despite AG being considered the gold pattern it always carries along an increased morbidity and limitation of the availability; in consequence development and use of biomaterials are a good alternative to be used in bone augmentation techniques (Nevins et al., 2009; Kolerman et al., 2008; Fagan et al., 2008; Cenni et al., 2009; Nevins et al., 2007; Turonis et al., 2006; Dallari et al., 2006).

Clinical and histological research aimed at the study of bone augmentation still presents doubts in terms of recognizing which biomaterial presents the best bone integration and best clinical performance. Histological studies in humans focus mainly on maxillary sinus lift (Choukroun et al., 2006; Cammack et al., 2005; Yukna \& Vastardis, 2005; Kassolis \& Reynolds, 2005; Lasella et al., 2003; Markopoulou et al., 2003), lateral or vertical increase of the alveolar ridge and bone regeneration by resection of residual cysts (Friedmann et al., 2009; Galindo-Moreno et al., 2008; Schwartz et al., 2007; Suga et al., 2006; Zerbo et al., 2001).

Although some research points out that in post exodontia socket, bone regeneration improves with the application of biomaterials (Iasella et al.), there is an interest in certain research groups to study this area (Chiapasco et al., 2006; Tonetti \& Hammerle; Donos et al., 2008), this in view of current results which are not necessarily a predictor

\footnotetext{
* Departamento de Odontología Integral, Facultad de Medicina, Universidad de La Frontera. Temuco, Chile.

** Laboratorio de Embriología Comparada, Facultad de Medicina, Universidad de Chile.

${ }^{* * * *}$ Dentistry Centre, Department of Maxillofacial Surgery, University of Göttingen, Göttingen, Germany.
} 
FUENTES, R.; OPORTO, V. G.; OLATE, S.; ROJAS, R. M.; BORIE, E. \& ENGELKE, W. Histological evaluation of bone regeneration means freeze dried bone allograft (FDBA) in post exodontia sockets. Int. J. Morphol., 29(1):286-292, 2011.

of success. (Chiapasco et al., 2008;. Cordaro et al., 2008; Rochietta et al., 2008; Antoun et al.). In view of the above it is interesting to indentify histological results in post exodontia sockets treated with commercially available biomaterials.

The aim of this research is to realize a histological, histochemical and histomorphometric analysis of two patients where Freeze Dried Bone Allograft (FDBA) was applied in their post exodontia sockets.

\section{MATERIAL AND METHOD}

Patients and surgical procedures. Two male patients 35 and 40 years of age were treated by the Oral Implantology Division of the Universidad de La Frontera during 2008. Both patients required rehabilitation of pieces 1.1 and 2.1 with a unitary crown installed over osseous integrated implant. In both patients teeth had received endodontic treatment and extensive restoration making further dental treatment impossible. Surgical sites presented inadequate alveolar ridge, absence of inflammatory processes and/or active infection. Bone reconstruction through the use of biomaterials and subsequent rehabilitation through assisted implant prosthesis unit (AIP) was indicated.

With administration of local anesthesia (2\% lidocaine with epinephrine 1:200.000), the first surgery consisted in the extraction of two pieces with high rotation drills in order to segment the radicular remnant and realize the exodontia in accordance with conventional techniques; subsequently FDBA cortical particle bone of 0.125 AND $0.850 \mathrm{~mm}$ was applied within the alveolar ridge (Community Tissue Service, a Department of Community Blood Center) with alveolar curette. Suturing was realized with 3-0 silk thread, simple suture without the use of membrane or any other type of protective element.

Six months later the second surgery was performed. Upon administration of local anesthesia (2\% lidocaine with epinephrine 1:100.000) mucoperiosteal flap was realized starting from lineal incision; bone material was obtained in the first stage by using a $2 \mathrm{~mm}$ internal diameter trephine, perforation was made in the center of the alveolar ridge previously grafted with FDBA. The specimen was submerged in buffered formalin at $10 \%$ and subsequently processed in the Comparative Embryology Laboratory of the Faculty of Medicine of the Universidad de Chile, through routine histological techniques 72 hours after collection. In a second surgical stage the site prepared with trephine was extended with surgical drills achieving a site for implant of $11 \mathrm{~mm}$ in length and $3.75 \mathrm{~mm}$ in diameter (internal hexagon) with a primary stability of $45 \mathrm{Ncm}$.

Histological and Histomorphometric study. Samples of bone tissue were decalcified and set to realize longitudinal $7 \mu \mathrm{m}$ cuts using microtome (Micron $®$ ). Subsequent staining with Hematoxylin-eosin and alcian blue (trichromic technique) (HEA), Masson (M), Von Kissa reaction (VK) and Picrosirius Junqueira method staining (PJ). Preparations were evaluated using optic microscope (Zeiss $\left.{ }^{\circledR}\right)$ with magnification of $50 \mathrm{X}$ and $100 \mathrm{X}$, using Axiovision $\AA$ computer software to identify bone structure (quality and quantity) vascular structure and inflammatory infiltrate. The histological and histomorphometric study was carried out in all images obtained.

\section{RESULTS}

Figure 1 (Figs. 1A, 1B, 1C and 1D) show histological images in case 1. Figure 1A (HEA) presents one tissue with extracellular acidophilus matrix and osteocytes included along with dense fibrillar tissue. In the bone trabeculae neither osteoblasts nor osteoclasts were observed in the endosteum, however some osteogenic cells were observed. In Figure 1 B (M) blood vessels were observed, probably neoformed, as well as transition between dense fibrillar tissue and bone matrix. Figure $1 \mathrm{C}(\mathrm{PJ})$ collagen type 1 was identified noted red in color, in view of the use of polarization microscope, in mosaic and with reduced longitude; collagen type III was not observed. Figure 1 D (VK) clearly indicates that the bone structure is not mineralized.

Figure 2 shows histological images for case 2. (Figs. 2A, 2B, 2C, 2D) Figure 2A (HEA) presents trabecular bone tissue with osteocytes in the matrix and few osteogenic cells in the endosteum. Neither osteoblasts nor osteoclasts were observed. With trichromic Masson stain, case 2 (Fig. 2B) exhibits two differences with case 1 (Fig. 1B). Trabeculae have mineralized, evidenced by the black color of the Von Kossa technique (Fig. 2 D), Haversian canals are in formation and connective tissue has changed from dense to lax in some segments.

Using Picrosirius Junqueira method stain (Fig. 2C) both cases present similar results observing collagen type I only. With the Von Kossa technique in Case 2 (Fig. 2D) trabeculae have mineralized and is evidenced by black color.

Histomorphometry of points carried out in the von Kossa method stain for evaluation of the bone tissue present 

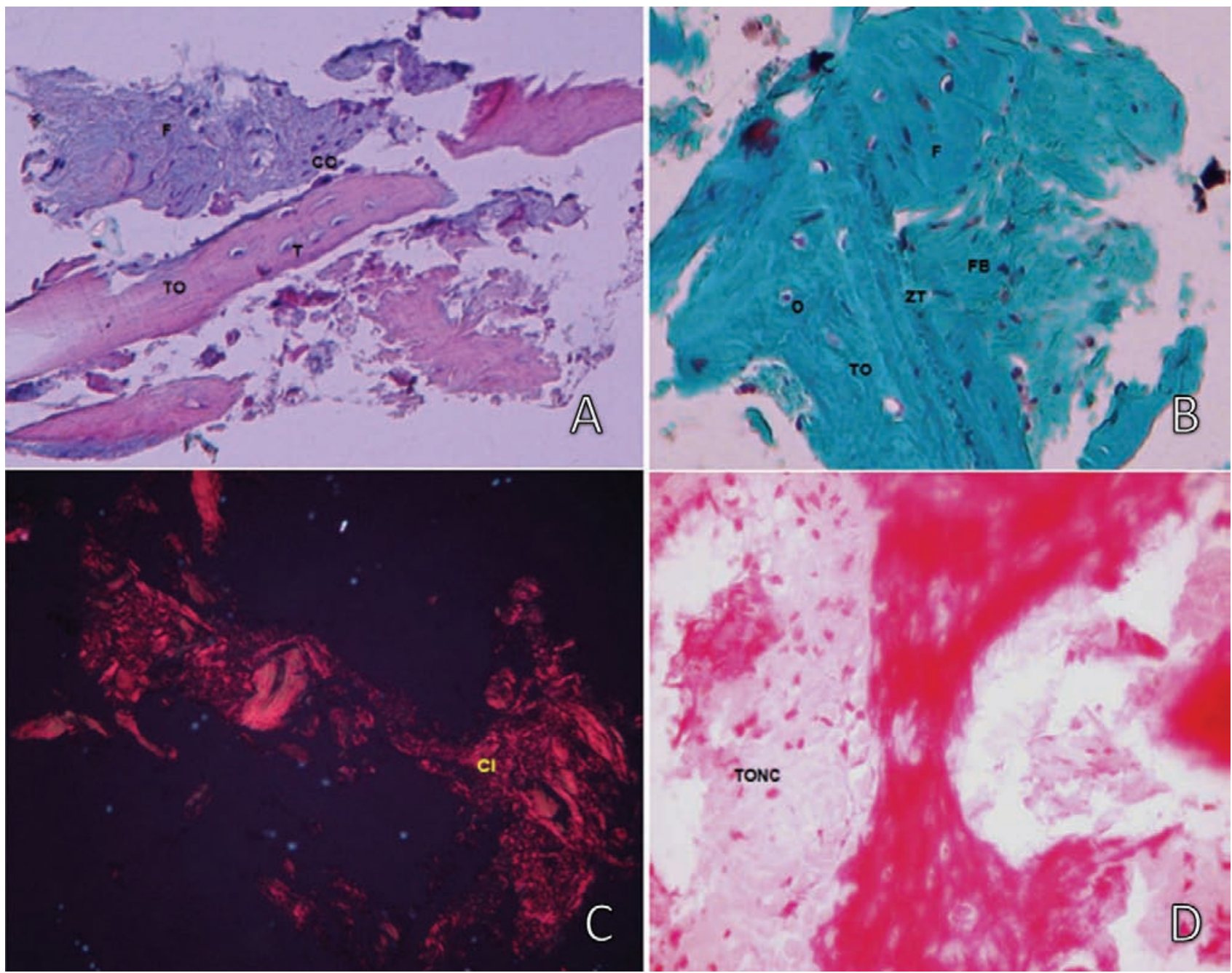

Fig. 1. Corresponds to case 1. A.- (HEA) Bone Tissue (BT), Plain osteogenic cells (OC), Bone Trabeculae (T). B.- (M) Transition area between dense fibrillar tissue and bone matrix (TA,), Osteocytes (O), Bone Tissue (BT), Fibroblasts (FB), Dense fibrillar tissue (F). C.(PJ) Type I collagen fibers (CI). Fig 1D (VK) Noncalcified bone tissue (NCBT).

in the samples, determining a complete absence of mineralized tissue in case 1 and $30 \%$ mineralized tissue in case 2 (Figs. 1D and 2D).

\section{DISCUSSION}

The use of biomaterials has been evaluated in various regenerative techniques (Friedmann et al.; Feuille et al., 2003; Herold et al., 2002; Rosen \& Reynolds, 2002; 2001; DaneshMeyer et al., 2001; Laurell et al., 1998), with limited research on the use of FDBA in post extraction alveolar ridges.

Neither osteoblasts nor osteoclasts were found in either sample, although osteocytes and osteogenic cells were observed. However, the fact of the sample presenting inactive osteogenic cells and that neither osteoblasts or osteoclasts were observed, does not mean that in this state of quiescence (metabolically inactive), rather that the bone genesis begins from the matrix of the tissue where cells with the potential or forming undifferentiated osteocytes and a micro environment with proteins of the growth factor family transforming beta as a morphogenetic protein of the bone, with participation of growth cells and factors from the fibrillar matrix (similar to that observed in the bone formation process during embryonic development) and not from osteoblasts. These finding differ from what has been presented as ideal bone regeneration processes, where according to advancement of osteogenesis (in bone regeneration induced by biomaterials), the matrix of fibrillar tissue regresses; formation of bone type I is completed by 

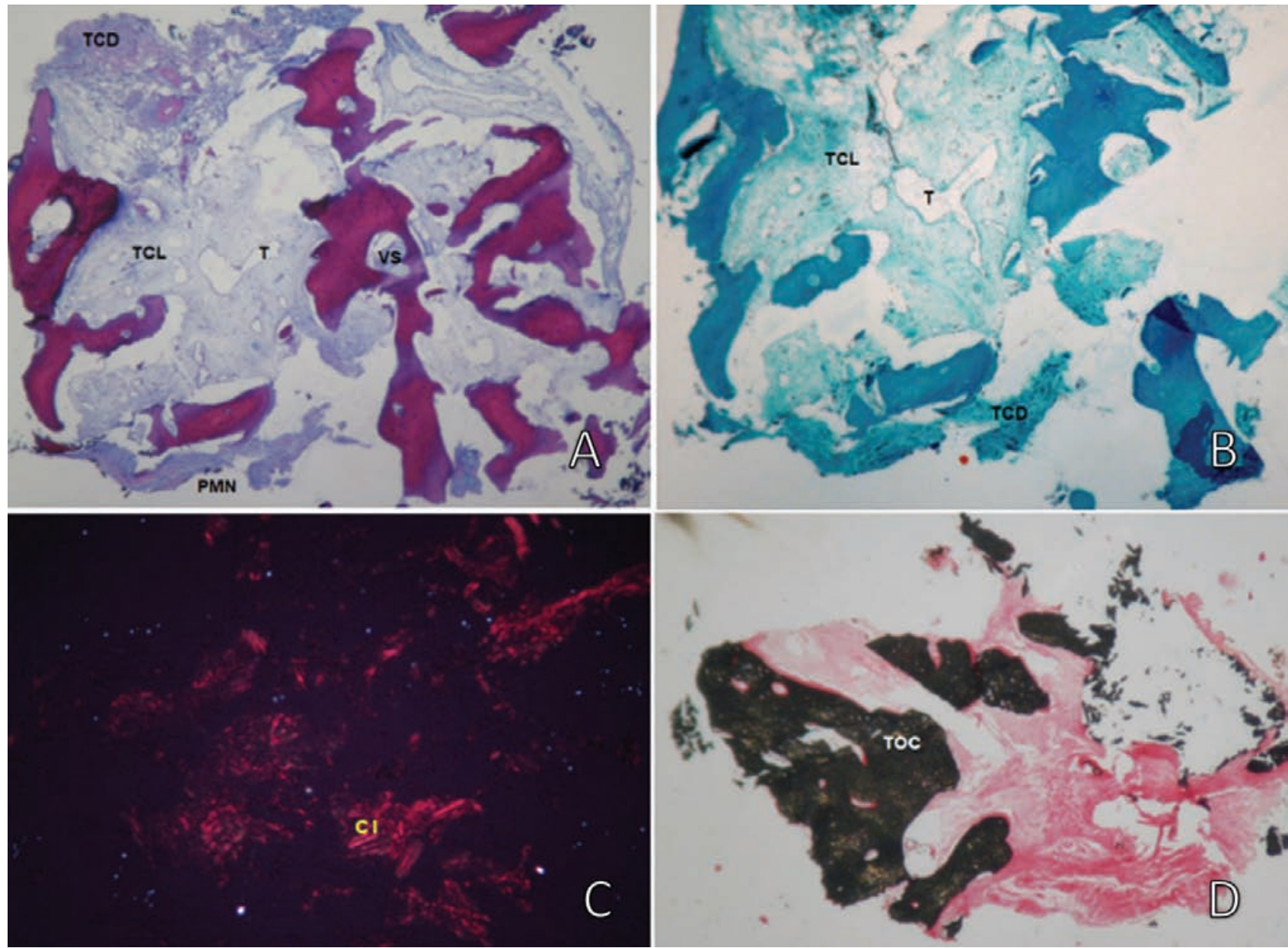

Fig. 2. Corresponds to case 2. A.- (HEA) Loose Connective Tissue (LCT), Dense Connective Tissue (DCT), Blood Vessels (BV), Polimorphonuclear Cells (PMC), Loose Matrix (LM). B.- (M) Bone Trabeculae (T), Loose Connective Tissue (LCT), Dense Connective Tissue (DCT). C.- (VK) Type I collagen fibers (CI). Fig. 1D (PJ) Calcified bone tissue (CBT).

the third or fourth week, and begins the phase of progressive substitution toward type II bone, where osteoclasts and osteoblasts appear (Anitua \& Andia, 2000). At the same time, it also differs with the results presented by other research (Galindo-Moreno et al.; Suba et al.; Friedmann et al.; Gotz et al., 2008; Lee et al., 2008; Norton et al., 2003, who have found that bone genesis produces starting with osteoblasts.

In case I non-mineralized bone trabeculae with osteocytes, dense fibrillar tissue and a transition between dense fibrillar tissue and bone matrix was observed. In case II, 30\% mineralized bone was found, the latter in accordance with parameters published in other research developed with biomaterial and methodologies different than those used in this research (Artzi et al., 2007); Norton et al.; Schwartz et al.; Galindo-Moreno et al.; Suba et al.; Friedmann et al.). Persistence of fibrillar tissue was observed in different amounts following six months after the application of biomaterial, although no remaining intact biomaterial was observed in any of the biopsies.

Furthermore, preservation of fibrous tissue areas for more than 4 weeks in a situation observed by other researchers using biomaterials (Lee et al.).

In view of results of this research, it is necessary to continue research associated to the relation between biomaterial and bone response in humans.

FUENTES, R.; OPORTO, V. G.; OLATE, S.; ROJAS, R. M.; BORIE, E. \& ENGELKE, W. Evaluación histológica de regeneración ósea en alvéolos post exodoncia de humanos mediante uso de freeze dried bone allograft (FDBA). Int. J. Morphol., 29(1):286292, 2011.

RESUMEN: Dentro de la rehabilitación oral, es importante preservar el reborde alveolar post exodoncia. Se expone un análisis histológico, histoquímico e histomorfométrico de dos ca- 
sos clínicos de terapias de regeneración ósea de alvéolos post extracción mediante FDBA. En dos pacientes se extrajeron piezas dentarias destruidas y se indujo regeneración ósea mediante FDBA. Seis meses después, se obtuvo una biopsia del injerto y mediante un implante de titanio fue rehabilitado. Para el análisis Histológico e Histomorfométrico, las muestras fueron tratadas con las técnicas Hematoxilina-Eosina, Azul de Alcián, Masson, Von Kossa y colorante Picrosirius de Junqueira. Se midió el área total de tejido, así como el área de tejido óseo. Las superficies de hueso de las muestras se observaron inactivas, no fueron encontrados osteoblastos ni osteoclastos, sólo osteocitos y células osteógenas, lo que no significa que el hueso esté en estado quiescente, sino mas bien a que su génesis ocurre a partir de la matriz de tejido donde se encuentran células con potencialidad de formar osteocitos indiferenciados y un microambiente con proteinas de la familia de factor de crecimiento transformante beta. No fueron encontradas partículas de biomaterial inactivo. En las muestras se cuantificó $0 \%$ y $30 \%$ de hueso mineralizado. Dadas las diferencias histológicas encontradas con otros estudios, es necesario profundizar el conocimiento en los procesos involucrados en la regeneración ósea dependiendo del biomaterial utilizado, y la calidad ósea resultante en cada procedimiento en particular sin perder de vista la variabilidad que puede presentarse dependiendo de cada caso clínico.

PALABRAS ClAVE: Regeneración ósea; Biomateriales; FDBA; Alvéolo.

\section{REFERENCIAS BIBLIOGRÁFICAS}

Anitua, E. \& Andia, I. Un nuevo enfoque en la renegeración ósea con plasma rico en factores de crecimiento $(P . R$. G. F). Victoria, Editorial Puesta al día publicaciones S.L., 2000. pp.49-78.

Antoun, H.; Sitbon, J. M.; Martinez, H. \& Missika, P. A prospective randomized study comparing two techniques of bone augmentation: onlay graft alone or associated with a membrane. Clin. Oral Implants Res., 12:632-9, 2001.

Artzi, Z.; Weinreb, M.; Carmeli, G.; Lev-Dor, R.; Dard, M. \& Nemcovsky, C. E. Histomorphometric assessment of bone formation in sinus augmentation utilizing a combination of autogenous and hydroxyapatite/biphasic tricalcium phosphate graftmaterials: at 6 and 9 months in humans. Clin. Oral Implants Res., 19:686-92, 2008.

Cammack, G.V. 2nd; Nevins, M.; Clem, D.S. 3rd.; Hatch, J.P.; Mellonig, J.T. Histologic evaluation of mineralized and demineralized freeze-dried bone allograft for ridge and sinus augmentations. Int. J. Periodontics Restorative Dent., 25:231-7, 2005.
Cenni, E.; Perut, F.; Ciapetti, G.; Savarino, L.; Dallari, D.; Cenacchi, A.; Stagni, C.; Giunti, A.; Fornasari, P. M. \& Baldini, N. In vitro evaluation of freeze-dried bone allografts combined with platelet rich plasma and human bone marrow stromal cells for tissue engineering. J. Mater. Sci. Mater. Med., 20:45-50, 2009.

Cordaro, L.; Amadé, S. D. \& Cordaro, M. Clinical results of alveolar ridge augmentation with mandibular block bone grafts in partially edentulous patients prior to implant placement. Clin. Oral Implants Res., 13:103-11, 2002.

Cordaro, L.; Bosshardt, D. D.; Palattella, P.; Rao, W.; Serino, G. \& Chiapasco, M. Maxillary sinus grafting with Bio-Osss or Straumanns Bone Ceramic: histomorphometric results from a randomized controlled multicenter clinical trial. Clin. Oral Implants Res., 19:796-803, 2008.

Chiapasco, M.; Colletti, G.; Romeo, E.; Zaniboni, M. \& Brusati, R. Long-term results of mandibular reconstruction with autogenous bone grafts and oral implants after tumor resection. Clin. Oral Implants Res., 19:1074-80, 2008.

Chiapasco, M.; Zaniboni, M. \& Boisco, M. Augmentation procedures for the rehabilitation of deficient edentulous ridges with oral implants. Clin. Oral Implants. Res., 17:136-59, 2006.

Choukroun, J.; Diss, A.; Simonpieri, A.; Girard, M.O.; Schoeffler, C.; Dohan, S.L.; et al. Platelet-rich fibrin (PRF): a second-generation platelet concentrate. Part V: histologic evaluations of PRF effects on bone allograft maturation in sinus lift. Oral Surg. Oral Med. Oral Pathol. Oral Radiol. Endod., 101:299-303, 2006.

Dallari, D.; Fini, M.; Stagni, C.; Torricelli, P.; Nicoli Aldini, N.; Giavaresi, G.; et al. In vivo study on the healing of bone defects treated with bone marrow stromal cells, platelet-rich plasma, and freeze-dried bone allografts, alone and in combination. J. Orthop. Res., 24:877-88, 2006.

Danesh-Meyer, M. J.; Filstein, M. R. \& Shanaman, R. Histological evaluation of sinus augmentation using platelet rich plasma (PRP): a case series. J. Int. Acad. Periodontol., 3:48-56, 2001.

Donos, N.; Mardas, N. \& Chadha, V. Clinical outcomes of implants following lateral bone augmentation: systematic assessment of available options (barrier membranes, bone grafts, split osteotomy). J. Clin. Periodontol., 35:173-202, 2008. 
FUENTES, R.; OPORTO, V. G.; OLATE, S.; ROJAS, R. M.; BORIE, E. \& ENGELKE, W. Histological evaluation of bone regeneration means freeze dried bone allograft (FDBA) in post exodontia sockets. Int. J. Morphol., 29(1):286-292, 2011.

Fagan, M. C.; Owens, H.; Smaha, J. \& Kao, R. T. Simultaneous hard and soft tissue augmentation for implants in the esthetic zone: report of 37 consecutive cases. J. Periodontol., 79:1782-8, 2008.

Friedmann, A.; Dard, M.; Kleber, B. M.; Bernimoulin, J. P. \& Bosshardt, D. D. Ridge augmentation and maxillary sinus grafting with a biphasic calcium phosphate: histologic and histomorphometric observations. Clin. Oral Implants Res., 20:708-14, 2009.

Feuille, F.; Knapp, C. I.; Brunsvold, M. A. \& Mellonig, J. T. Clinical and histologic evaluation of bonereplacement grafts in the treatment of localized alveolar ridge defects. Part 1: Mineralized freeze-dried bone allograft. Int. J. Periodontics Restorative Dent., 23:29$35,2003$.

Galindo-Moreno, P.; Avila, G.; Fernandez-Barbero, J. E.; Mesa, F.; O’Valle-Ravassa, F. \& Wang, H. L. Clinical and Histologic comparison of two different composite grafts for sinus augmentation: a pilot clinical trial. Clin. Oral Implants Res., 19:755-9, 2008.

Götz, W.; Gerber, T.; Michel, B.; Lossdorfer, S.; Henkel, K-O. \& Heinemann, F. Immunohistochemical characterization of nanocrystalline hydroxyapatite silica gel (NanoBones) osteogenesis: a study on biopsies from human jaws. Clin. Oral Implants Res., 19:1016-26, 2008.

Herold, R. W.; Pashley, D. H.; Cuenin, M. F.; Niagro, F.; Hokett, S. D.; Peacock, M. E.; et al. The effects of varying degrees of allograft decalcification on cultured porcine osteoclast cells. J. Periodontol., 73:213-9, 2002.

Iasella, J. M.; Greenwell, H.; Miller, R. L.; Hill, M.; Drisko, C.; Bohra, A. A.; et al. Ridge preservation with freezedried bone allograft and a collagen membrane compared to extraction alone for implant site development: a clinical and histologic study in humans. J. Periodontol., 74:990-9, 2003.

Iizuka, T.; Smolka, W.; Hallermann, W. \& Mericske-Stern, R. Extensive augmentation of the alveolar ridge using autogenous calvarial split bone grafts for dental rehabilitation. Clin. Oral Implants Res., 15:607-15, 2004.

Kassolis, J. D. \& Reynolds, M. A. Evaluation of the adjunctive benefits of platelet-rich plasma in subantral sinus augmentation. J. Craniofac. Surg., 16:280-7, 2005.
Kolerman, R.; Tal, H. \& Moses, O. Histomorphometric analysis of newly formed bone after maxillary sinus floor augmentation using ground cortical bone allograft and internal collagen membrane. J. Periodontol., 79:2104-11, 2008.

Laurell, L.; Gottlow, J.; Zybutz, M. \& Persson, R. Treatment of intrabony defects by different surgical procedures. A literature review. J. Periodontol., 69:303-13, 1998.

Lee, J. H.; Jung, U. W.; Kim, C. S.; Choi, S. H. \& Cho, K. S. Histologic and clinical evaluation for maxillary sinus augmentation using macroporous biphasic calcium phosphate in human. Clin. Oral Implants Res., 19:76771, 2008.

Markopoulou, C. E.; Vrotsos, I. A.; Vavouraki, H. N.; Dereka, X. E. \& Mantzavinos, Z. S. Human periodontal ligament cell responses to recombinant human bone morphogenetic protein-2 with and without bone allografts. J. Periodontol., 74:982-9, 2003.

Nevins, M. L.; Camelo, M.; Nevins, M.; Schupbach, P.; Friedland, B.; Camelo, J. M.; et al. Minimally invasive alveolar ridge augmentation procedure (tunneling technique) using rhPDGF-BB in combination with three matrices: a case series. Int. J. Periodontics Restorative Dent., 29:371-83, 2009.

Nevins, M.; Hanratty, J. \& Lynch, S. E. Clinical results using recombinant human platelet-derived growth factor and mineralized freeze-dried bone allograft in periodontal defects. Int. J. Periodontics Restorative Dent., 27:4217, 2007.

Norton, M. R.; Odell, E. W.; Thompson, I. D. \& Cook, R. J. Efficacy of bovine bone mineral for alveolar augmentation: a human histologic study. Clin. Oral Implants. Res., 14:775-83, 2003.

Oporto, G.; Fuentes, R.; Álvarez, H. \& Borie, E. Recuperación de la morfología y fisiología maxilomandibular: Biomateriales en regeneración ósea. Int. J. Morphol., 26:853-9, 2008.

Rocchietta, I.; Fontana, F. \& Simion, M. Clinical outcomes of vertical bone augmentation to enable dental implant placement: a systematic review. J. Clin. Periodontol., 35:203-15, 2008.

Rosen, P. S. \& Reynolds, M. A. A retrospective case series comparing the use of demineralized freeze-dried bone allograft and freeze-dried bone allograft combined with 
FUENTES, R.; OPORTO, V. G.; OLATE, S.; ROJAS, R. M.; BORIE, E. \& ENGELKE, W. Histological evaluation of bone regeneration means freeze dried bone allograft (FDBA) in post exodontia sockets. Int. J. Morphol., 29(1):286-292, 2011.

enamel matrix derivative for the treatment of advanced osseous lesions. J. Periodontol., 73:942-9, 2002.

Rosen, P. S. \& Reynolds, M. A. Guided bone regeneration for dehiscence and fenestration defects on implants using an absorbable polymer barrier. J. Periodontol., 72:2506, 2001.

Schwartz, Z.; Goldstein, M.; Raviv, E.; Hirsch, A.; Ranly, D. M. \& Boyan, B. D. Clinical evaluation of demineralized bone allograft in a hyaluronic acid carrier for sinus lift augmentation in humans: a computed tomography and histomorphometric study. Clin. Oral Implants Res., 18:204-11, 2007.

Smolka, W.; Eggensperger, N.; Carollo, V.; Ozdoba, C. \& Iizuka, T. Changes in the volume and density of calvarial split bone grafts after alveolar ridge augmentation. Clin. Oral Impl. Res., 17:149- 55, 2006.

Suba, Z.; Takacs, D.; Matusovits, D.; Barabas, J.; Fazekas, A. \& Szabo, G. Maxillary sinus floor grafting with btricalcium phosphate in humans: density and microarchitecture of the newly formed bone. Clin. Oral Implants Res., 17:102- 8, 2006.

Tonetti, M. S. \& Hammerle, C. H. Advances in bone augmentation to enable dental implant placement: Consensus Report of the Sixth European Workshop on Periodontology. Clin. Periodontol., 35:168-72, 2008.

Turonis, J. W.; McPherson, J. C. 3rd.; Cuenin, M. F.; Hokett, S. D.; Peacock, M. E. \& Sharawy, M. The effect of residual calcium in decalcified freeze-dried bone allograft in a critical-sized defect in the Rattus norvegicus calvarium. J. Oral Implantol., 32:55-62, 2006.

Yukna, R. A. \& Vastardis, S. Comparative evaluation of decalcified and non-decalcified freeze-dried bone allografts in rhesus monkeys. I. Histologic findings. J. Periodontol., 76:57-65, 2005.

Zerbo, I. R.; Bronckers, A. L. J. J; de Lange, G. L.; van Beek, G. J. \& Burger, E. H. Histology of human alveolar bone regeneration with a porous tricalcium phosphate. A report of two cases. Clin. Oral Implants Res., 12:37984, 2001.
Dirección para correspondencia:

Prof. Dr. Med. Dent. Ramón Fuentes Fernández

Profesor Asociado

Departamento de Odontología Integral

Facultad de Medicina

Universidad de La Frontera

Manuel Montt 112

Temuco

CHILE

Email: rfuentes@ufro.cl

Recibido : 17-08-2010

Aceptado: 19-11-2010 